\title{
Effect and eco-friendly management of brinjal shoot and fruit borer (Leucinodes orbonalis Guenee) on brinjal
}

\author{
R.K. DWIVEDI*1, AKHILESH TRIPATHI ${ }^{2}$, R.K. PAL ${ }^{1}$ AND D.K. SINGH ${ }^{1}$ \\ ${ }^{1}$ Department of Entomology, C.S. Azad University of Agriculture and Technical, KANPUR (U.P.) INDIA \\ ${ }^{2}$ Department of Entomology, Kulbhaskar Ashram (P.G.) College, ALLAHABAD (U.P.) INDIA
}

\begin{tabular}{l} 
ARITCLE INFO \\
\hline Received : 18.02 .2014 \\
Revised $\quad: 18.07 .2014$ \\
Accepted : 04.08 .2014 \\
\hline KEY WORDS : \\
Brinjal, Leucinodes orbonalis, Eco- \\
friendly management \\
*Corresponding author: \\
Email: tripathi_ak@yahoo.co.in \\
\hline
\end{tabular}

\begin{abstract}
Brinjal shoot and fruit borer, Leucinodes orbonalis Guenee is a very serious insect of brinjal. During the present investigation, six insecticides were evaluated under field conditions. Regarding the efficacy of insecticides, Imidacloprid 17.8 SL @ $250 \mathrm{~g}$ a.i./ha proved most effective which was closely followed by Indoxacarb 14.5 SC @ $50 \mathrm{~g}$ a.i./ha and Dimethoate $30 \mathrm{EC} @ 1$ lit/ha. Maximum fruit yield ( $220.61 \mathrm{q} / \mathrm{ha}$ ) was obtained by the treatment of Imidacloprid followed by Indoxacarb (217.88 q/ha) and Dimethoate (216.22 q/ha).
\end{abstract}

How to view point the article : Dwivedi, R.K., Tripathi, Akhilesh, Pal, R.K. and Singh, D.K. (2014). Effect and eco-friendly management of brinjal shoot and fruit borer (Leucinodes orbonalis Guenee) on brinjal. Internat. J. Plant Protec., 7(2) : 287-291. 